伴5肝重量変化の概覾を試み, 次の結果を得た．1）高

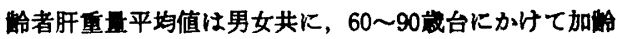
と共に直線的に減少し，同年代では男性は女性に比し 5 10\%高値を示した，2）肝重量/体重比は，男女共 に加綸と共に減少し，その減少は60〜70戚で著しく，ま た重量比は女性が男性より高い㑯向を示した。

30. ヒト肝湅胞内におけるビタミン $\mathbf{B}_{12}$ 代期におよほ す加的の影雫

$$
\begin{aligned}
& \text { 京大 老年科稲田 雅美, 豊島 正意 } \\
& \text { 杉山线, 正邦 }
\end{aligned}
$$

目的：ヒト肝細胞内のビタミン $\mathrm{B}_{12}$ (Cbl.) 代謝にお よぼす加羭の影籍を明らかにする. 方法：ヒト剖検肝 を用いた。肝の細胞内分画を恝遠心分倠法により分離し た. 各分画内の $\mathrm{Cbl}$ 量および Cbl 源道体，とくに活性 型 Cb (メチル型, 補酻素型)を定是した。これらを老 年者群と若年者群との間で比艾した. 結果: (1) 総 $\mathrm{Cbl}$ 量は両群間で有意差はない（2) ミトコンドリフを含む 分画では老年者で低下し，(3) 活性型 Cbl はメチル型 は低下し，補醉型は上昇傾向を示した。

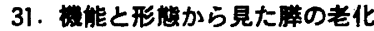

岡大 第二内科

三島 邦基, 中村' 䈏彦，植田修

安岡 正敏, 原田 英雄, 木村 郁郎

傽の老化について検討することを目的とし，18〜78歳 の脺疾患を有さない117例を対象として, PS test - ERCP. 加䚟の関係 Кついて比較検討し，以下の結論をえた。

（1）脺外分泌機能は加踰とともに低下する：(2) 主

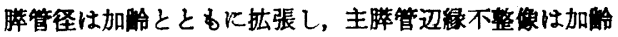

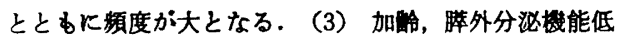

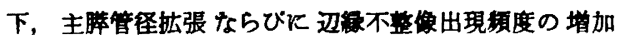
は，互いに相関威係にある.

\begin{tabular}{|c|c|c|}
\hline 音羽 & 院 内科 & 軦島 \\
\hline 同 & 外科 & 阪口 \\
\hline 京大 & 老年科 & \\
\hline
\end{tabular}

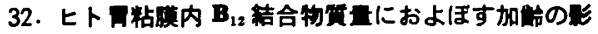
in

ヒト胃粘膜内内因子量および R-binder 量の加溚によ る影要を，手術による摘出胃により検討した. すなわち

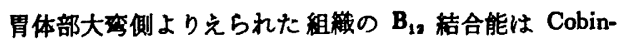

amide を用いる albumin coated charcoal 法により测定 した．前底部よりえられた粘膜よりは，ガストリぬ是を

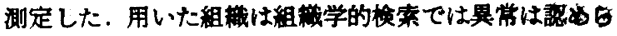
れなかった。胃粘膜内内因子量，R-binder 量は病变性虽 にかかわらず加鮯により減少し，粘膜内ガストリンをと る相威した。

33. 高粭者の㵢脱型食道裂孔ヘルニア 信州大第一外科荻原 迪彦, 西牧 敬二 草野 充郎, 林 四郎

1969年以降，当科で治亦した渭脱型食道裂孔ヘルニフ 18例（男性 6 例，女性12例）中，自賞症状，令道炎脷 見が强い14例対して主として食道裂孔䋖縮に加えて Nissen 法を実施し良好な結果を得た。1 例の小児例を除 き，平均年秢は68藏で，高䑪者が多く，そのため年略に 闺連した合併症を有する例も多いが，発症後経過期间が 短くてす逆流性食道炎の出現密が高い本症に対しては高

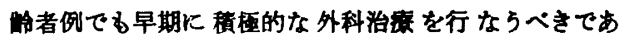
る.

\section{4. 老人病院の注意すべき履部疾急}

鞍手共立病院西原 康推, 石井 惟友 当院連繶剖検例中, 70 嵅以上の 高峆者633例の 腹部疾 患を検索した。消化性流清63例（穿孔・腹膜炎 5 例，消 化管出血死14例)，虚血性腸炎17例，子宮炎 4 例，種々

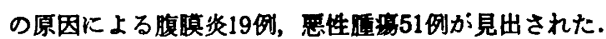
特徼的な症状を呈さないことす少なくなく，また，疾呆 や䒠たきりの患者が多いため十分な検査を行い得ず，剾

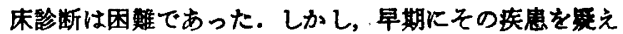
ば，外科的処膡の可能な场合むあると考えられる。

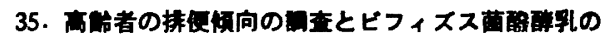
领用に伴う排便回数への影空

$\begin{array}{ll}\text { ヤクルト中央研 } & \text { 田中隆一郎 } \\ \text { 社会福祉法人 黒潮国 } & \text { 下坂 国雄 } \\ \text { 和歌山医大 内科 } & \text { 宮村 敬 }\end{array}$

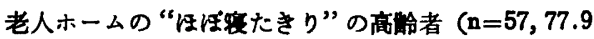

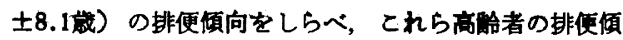
向の改善にビフィズス菌酰醉我の飭用が有用であること を長期個人追跡法で明らかにした。すなから，高峆者に は便秘薬常用者が多く(39\%)，かつビ菌酰醅乳の 领用 により，自然排便者では平均5.6 $\rightarrow 8.1$ 回/10日間，便秘菜 常用者は2.1 $\rightarrow 4.4$ 回/10日間のよ5に，いずれも领用期 
間中は排便回数が有意に. $(p<0.01)$ 增加することが分 った.

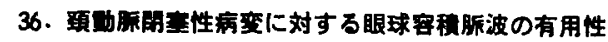

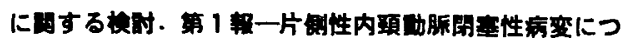
แT-

\section{北里大 内科}

林 辺晃, 坂井 文彦, 古栝 紀久 神田直, 田䓫 義昭

川绮市立井田病院 神経内科早川功 内頚動脈閉塞性病変の非微血的検查として, 新しい眼 球容棈原波記錄計（OPG 100-A）の有用性につき，脳 血管写所見と比較して検討した．OPG で片側珄内頝動 脈病変と判定された症例のうち, $86 \%$ 病側内頚動脈の 50\%以上の狭窄又は完全閉塞を認めた. 正常とされたも のては，50\%以上の怗窄をみたすのは12\%にすぎなかっ た. OPG は，預動脈閉㕩性病変の有無を非䍹血的に診 断する方法として，安全かつ简便で有用であると考え る.

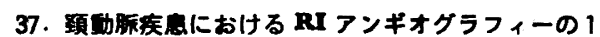
考宗

$$
\begin{aligned}
& \text { 大阪将立成人病センター 内科 } \\
& \text { 讯見 和郎，松原 教，広瀬 意夫 } \\
& \text { 刀翮 健治, 吉田 茂 } \\
& \text { 同アイントーフ診亦科 中野 俊一 } \\
& \text { 同故射線科大川 元臣 }
\end{aligned}
$$

RCAG を行った症例150例中脳血管撮影にて証明され た頝動脈閉塞, 高度㹟窄例の計 9 例を選択し, 従来のイ メージ診断をより客観化されたるのとするため, 関心領 域から求めた first positive peak (FPP) の1) 出現時間, 2) peak 值について検討した. 前者は患側で健側に比し, 又同僋です㹟窄前後にて㱠んどの例で幄延を示した。後 者は狭窄部でかえって增大する例むあり，㹨窄の程度， 副血行路等の関与により変化することが推定された．

\section{8. 譄梗基の研究一特に血管写上の䵢脈硕化度につい} $\tau-$

$$
\begin{array}{ll}
\text { 聖マリフンナ医大 } & \text { 第二内科 } \\
& \text { 須階 二朗, 清水 学 } \\
\text { 同 第三内科 山田 充, 高橋 洋一 } \\
\text { 同 放射線科 } \\
\text { 杉原 浩, 米山 公啓, 芦田 浩 }
\end{array}
$$

脳梗塞25例を CT 上，所見を認めぬ N群，内包付近に 低吸収像を恐める穿通枝梗塞 S 群, くさび状の低吸収像 を認める皮質枝梗塞 L群、脳萎䈹像を呈するA 群の 4 群 に分け，陳旧期に施行した脳血管写より Greitzの变法 により動脈硬化度を求め検討した。N群は軽度， $\mathrm{S}$ 群は 中等度，A群は高度の動脈硬化度をしめした，L群では 主幹動脈の閉塞を呈する例が多く，これらの例では反対 側の血管写より動脈硬化度を求め，高度な動脈硬化度を 㤎めた。

39. 地域离血圧者の CT 所見第 2 基底核部小梗 慗について一

秋田県立脳血管研究センター 内科

$$
\text { 鈴木一夫, 沓沢 尚之 }
$$

秋田県雄和町高血圧者を対象として，無症候性基底核 部梗塞の出現率およびリスクファクターを検討した。そ の結果，高耣になるにしたがいCT で発見される基底核 梗篹出現率は上㫒し，血清総コレステロール，LDL の 低値を示するのに梗塞が多く㸾められることがわかっ た.ここで認められた無症候性小梗塞の臨床的意義, 特 に高血圧性脳出血との関連を考察した.

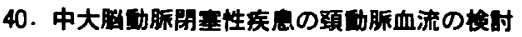 阪大 第一内科 \\ 浅井 勉, 津田 能康, 恵谷 秀紀 宮井 元伸, 米田正太郎, 今泉 昌利 木村 和文, 阿部裕}

中大脳動脈閉塞性病変を有する症例 (中大缼動脈 $\mathbf{M}_{1}$ 部閉塞症 8 例, 同狭窄症 6 例) 及び対照として内頝動 脈，中大脳動脈に血筸写上閉塞性病変を認めない脳血管 障害14例につき総頊動脈血流を超音波ドップラー血流計 を用いて娭討した．胘血管写上後大揆動脈より側副血行 のみられる中大脳動脈閉塞例では患側総頊動脈血流は健 側に比し低い㑯向がみられたか，これのみられない閉塞 例，㹟若例及び対照群では，左右差を認めなかった。

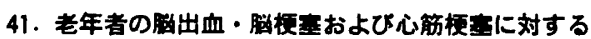

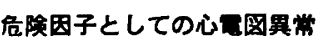

国立循環器病センター 内科 横内 正利, 池田 正男

浴風会病院

鈴木 孝臣, 伊東 由夫, 関 增爾 化学療法研付属病院寺沢富士夫 